\title{
Black Women and Racism - An in Depth Study of Song in the Front Yard by Gwendolyn Brooks
}

\author{
K. K. ABITHAA M.A., English
}

Nadar Saraswathi College of Arts \& Science, Theni, Tamil Nadu, India

\begin{abstract}
The paper aims to gives an in depth study of Gwendolyn brooks' poem A song in the Front yard, from the feminist perspective; concentrating on the experience of Black women in particular during the 1960 's. Feminism is a movement beginning from the late $19^{\text {th }}$ century, asking for equal rights for women in all spheres; but it is said to have concentrated on the experience of white women only. The inequity against black women wasn't taken into deliberation. It took women like sojourner Truth and others to voice out for the blacks. Gwendolyn Brooks come in this line of black women writers who spoke for the cause of their people. Her poetry reflects the life of the black women of that time.
\end{abstract}

Keywords-Black Women, Racism, Gwendolyn Brooks.

\section{ABOUT RACISM}

Racial discrimination is," The assertion to facilitate heated discussion description for divergence in personage personality or knack and that a scrupulous pursuit is superior to others." Also, racism is, "intolerance or chauvinism based on revealing." When slavery was exceptional in the United States, blacks were not only considered substandard to whites but regarded as property instead of human beings. During the 1787 Philadelphia Convention, it was agreed that slaves were to be considered three-fifths people for purposes of taxation and demonstration. Generally during slavery, blacks were deemed academically inferior to whites. This notion persists in modern-day America .In 1994, a book called The Bell Curve pointed that genetics were to blame for why African Americans traditionally score lower on astuteness tests than whites. The book was attacked by every New York Times columnist bob Herbert, who argued that societal factors were accountable for the disparity, to Stephen Jay Gould, who argued that the author's ended conclusions unconfirmed by accurate scrutinize.

\section{A SONG IN A FRONT YARD VIEW OF RACISM}

On the exterior of Gwendolyn Brook's poem, "a song in the front yard", is a girl who wants to participate in the "back yard" and "have some fantastic fun" as a proxy of staying in the fascia patio, but the deeper memorandum is not just concerning more fun, but about a girl who yearns to have a life she is not sufferable to have.

In this poem; that she is a juvenile girl. In line four, the speaker refers to herself as a girl; the word "girl" has refers association as a younger female. The following lines sound very demanding and juvenile:

"I require to go in the back yard at this time

And maybe down the alley

To where the children play

I want a good time today."

The words "want" and "now" define the selfish tendencies of child. The consequence of the communication being a young girl comes from the fact that young children are usually ill-bred to wealth and status. The young children only want fun and enjoyment in their life. The profile status becomes eminent in determining these all refers the social relationship.

The speaker uses the symbolic front yard to infer status. The imagery beings on the first line on the poem where Brooks discusses that the speaker has stayed in the front yard all her life she portentous a desire for change. On a factual meaning, the front yard is a place people can see from the street. It is generally inviting, orderly, and beautiful. This leads one to assume a front yard can represent order, constancy, and status on a symbolic level. The speaker is apparently jaded with her life in the front yard as is made clear when she says," A girl gets sick of a rose". The rose is a stunning rich flower; only one with money would be able to get "sick" of it. A flipside yard is," Where it's jagged and untended and famished prearranged grows". The back yard usually is not well kept because it is unseen, symbolizing how the deprived are care free and exploratory due to not being" radar" so to speak.

The backyard is representatively a place for the poor, and consequently it becomes a place for the repulsive in society. In one sense, Brooks utilizes the backyard as a place where people hide things for example wealthy people hiding the nauseating," Hungry weed" in the backyard. But 
the backyard is not only seen as the physically ugly place, but it has connotations of bad people. As the mother lists the types of people correlate with the backyard, she says," That George will be taken to jail soon or late". The prominence on back gate flanking theft and jail reinforces the hideousness and bad that link to the backyard. In toting up the word "jail" is capitalized screening that it has significance. It suggests that if the girl goes in to back yard she will be exposed to the bad in the world.

However, in another sense, Brooks crowns the backyard as a place that the flourishing person wants to be. A sort of secret garden for this young wealthy girl as she desires to explore the enigmatic freedom the poor live with. In this sense the poor children are not forced to play in the patch they are allowed to play there; while the rich girl is chained to her front yard of responsibility and strict confines. When the girl voices her desire to play with the children in the patch, the mother sneers. The mother describes how much trouble the kids in the patch will get the speaker in, but the speaker continues to desire to do some wonderful things and goes against what her mother says. The unswerving inaptness between the mother and the daughter, connect to the unawareness and lenience younger children tend to have. In the beginning of the poem, it seems likely the speaker is a young child, but the last stanza she imagines how she wants to be a woman. She says," And I had like to be a ghastly woman, too and wear the prop stocking of night-black lace and flounce down the streets with paint on my face". This justification of a woman in makeup and black lace stockings is of person in the back yard, a poor person, but a woman not a child. The younger fantasize about playing in the lane where the woman fantasizes about" prance down the street". The change from a child to a woman symbolizes the transition of adolescents overcoming the segregations made by wealth.

The rhyme scheme is unvarying throughout the poem excepting for the last stanza connecting to the change from a juvenile to a woman. The rhyme scheme established for the preponderance of the poem is abcc, where the first two lines do not follow an established rhyme but the third and forth from a rhyme. But the last stanza forms two rhyming couplets:

But I say it's fine. Honest, I do.

And I'd like to be a bad woman, too.

And wear the brace stockings of night-black lace.

And strut down the streets with paint on my face.

The words "do" and "too" connect through end rhyme and "lace" and "face" connect through end rhyme. The unfailing new pattern shown in the last stanza relates to the new association established for the speaker. Gwendolyn Brook's poem "a song in the front yard" uses the first person narrative and imagery to exhibit the satire and relationship between the wealthy and poor. The young speaker shows how teens include ignorance by desiring to go against her mother and play in the back yard. In the front yard and back yard indicate the diverse life styles: The amiable, un-kept poor life style of the back yard, that the flourishing chronicler living" in the obverse patio envies and the wealthy people belittling in their front yards. Brooks reinforces that ignorance leads to tolerant and allows the girls to desire close the gap of severance.

Conclusively, Gwendolyn Brooks" A song in the front yard" can stalwartly materialize to be a relating by an naive girl who is naive of the unsuitable nature associate with the activities of which she is junk. As such, all of the scholars who examine the poem use this frame work when analyzing it. This inclination is most likely due to the hegemonic communal norm of understanding adolescents through the lens of innocent and ingenuousness, coupled with the notion the parents can shield their children with "front yards". Janssen supplements this construal by noting "the poem highlights several forces working against each other train to find some way to resolve the strain of personage desire and parental and social anticipation". The poem destabilizes societal assumptions related to adolescents by illustrating that they are far more cunning and clever then they are assumed to be. Thus, the same lines used to support the "innocent, native girl" framework can be alternatively used to describe" A Song in the Front Yard". As a melody laced with equal parts defiance, manipulation and sexual activity. Additionally, the tri-layered approach to examining the novel brings new meaning to the title of the poem. In the literalist approach, the girl is taunting her mother; however, within the tri-layered lens, her song is far more profound-it serves as a harmonious avowal of racial pride and equality.

\section{REFERENCES}

[1] Brooks, Gwendolyn." A Song in the Front Yard". The Norton Anthology of modern and contemporary poetry: Volume to. Ed. Jahan Ramazani, Richard Ellaman and RobertO' Clair. New York NY: W.W. Norton \& company, 2003 .141 .print.

[2] Melham, D.H.Gwendolyn Brooks, poetry \& the heroic voice.Lexington, KY: University press of Kentucky, 1987.print.MacGowan, Christopher. Twentiethcentury American poetry. Maldon, MA: Blackwell pub., 2004.print. 
[3] Clark, Keith." A thousand Different Points of View." Ann Petry's Short Fiction: Critical Essays.Ed.Hazel Ervin and Hillary Holladay. Westport, CT: praegor publishers, 2004 76-96.print.

[4] Wheeler, Lesley. The poetics of enclosure: American Women poets from Dickinson to Dove.Knoxville, TN: University of Tennessee press, 2002.print.

[5] Ramazani, jahan.A transnational poetics Chicago, IL: University of Chicago press, 2009.print.janssen, Ronald.'Brook's A song in the Front Yard."Explicator 43.3(1985):43.print. 